\title{
SChoOl Tourism: a NeW Perspective Of IMPlementing SchoOL Physical Education in Poland
}

\author{
Piotr Oleśniewicz ${ }^{1}$; Halina Guła-Kubiszewska ${ }^{2}$; Julita Markiewicz-Patkowska ${ }^{3}$ \\ ${ }^{1}$ University School of Physical Education in Wrocław, Faculty of Physical Education, \\ Department of Tourism and Recreation, al. I.J. Paderewskiego 35, 51-612 Wrocław, Poland; \\ Wrocław School of Banking, Faculty of Finance and Management, Department of Tourism, \\ ul. Fabryczna 29-31, 53-609 Wrocław, Poland \\ ${ }^{2}$ University School of Physical Education in Wrocław, Faculty of Physical Education, \\ Department of Physical Education, al. I.J. Paderewskiego 35, 51-612 Wrocław, Poland \\ ${ }^{3}$ Wrocław School of Banking, Faculty of Finance and Management, Department of Tourism, \\ ul. Fabryczna 29-31, 53-609 Wrocław, Poland \\ e-mail: ${ }^{1}$ piotr.olesniewicz@awf.wroc.pl; ${ }^{2}$ halina.gula-kubiszewska@awf.wroc.pl; \\ julita.markiewicz-patkowska@wsb.wroclaw.pl
}

\begin{abstract}
The aim of the study was to explore the Polish physical education students' opinion on their ability to conduct tourism classes as part of the obligatory physical education classes in school education. The authors also tried to determine the students' preferred paradigm of a school tourism teacher. The study was performed among all $1^{\text {st }}$ year students of the $2^{\text {nd }}$ degree studies after completing the subject of school tourism, which is taught within a 30-hour course and ended with an examination. The methods of a diagnostic poll and a questionnaire were applied, with the HGK/PO-2009/10-II/I/IS questionnaire prepared by the authors. The study was anonymous and voluntary, and involved 114 students.
\end{abstract}

\section{Introduction}

Tourism plays an important role in social life. It is particularly significant as a form of relaxation, cognition, gaining knowledge, and restoration of both physical and mental strengths [1]. Tourism is a human activity defined as temporary spatial migration of population.

The essence of the phenomenon, in the social sense, is determined by the purpose of a journey, while the diversity of purposes makes tourism dynamic. The number of people taking part in tourist journeys is increasing and thus tourism is becoming a mass phenomenon, of complex and heterogeneous character, rich in its content. Tourists are people who visit different places to satisfy their recreational, health, sightseeing, professional, sports, religious, family, social or political needs. Motives for travelling include leisure, business, health, studying, conventions, visiting family or friends, as well as religious and sports aspects. The dynamics of tourism depends on the influence of the environment; it is also connected with the character of tourism and the needs it satisfies. The main boost factors of tourist traffic are economic prosperity, the ease of travelling, the increase of the amount of free time, and personal motives for journeys. Social and economic changes are accompanied by changes in the objectives of travelling, in travelers' requirements and expectations, and in the behaviour of a contemporary tourist. Tourists associate tourism with freedom, the ease of changing the place of stay, discovering foreign countries, societies, cultures, or monuments of history. Recreational purposes are frequently combined with education and entertainment, the search for attraction, difference, diversity, new experiences and sensations. The basis for initiating 
tourist activity is motivation, being co-related with the utility and the value of a certain action for an individual, and the probability of its accomplishment. It must be remembered that motivation is a dynamic process. It tends to change and transform under various influences, also the influence of school. The initial motives for involvement in tourist activity differ from those that will lead people to continue doing so. The inner motivation results from the system of values, interests and ambitions of a pupil. What also plays an important role, though, is the outer motivation, influencing a pupil by the means of a colourful advertisement, stories told by friends or relatives, television programmes, or teachers. In school education, it is becoming crucial to prepare pupils to choose a model of a modern tourist: a mass, individual or corporate one, an explorer or a drifter (a tramp).

An unceasing dynamics of the international tourist movement in the world has been observed over the last few decades, owing to the processes of the global economy: the increase of prosperity in wealthy societies, new countries joining the path of rapid development, a greater amount of leisure time, and progress in the means of transport [2]. The World Tourist Organization predicts that in 2020, the international traffic will reach 1,561 million in the world (717 million in Europe) in supply (the figures for 2007 were 898 million in the world and 498 million in Europe). Indisputably, this poses a challenge for school education. What will be the role chosen by school? Will it join the global trend?

Participation in the tourist traffic can result in both positive and negative consequences in the scope of the biological and psychosocial spheres. Active tourism improves one's health and organism efficiency, keeps individuals fit and provides the opportunity to abide in the ecological environment. It induces relaxation and stress relief, inspires emotional sensations, but also enriches intellectually, shapes new interests or passions, and helps to understand the world. It has been observed that tourism affects young people in an especially positive way. Tourism might be a tool for socialization, as well as creation of pro-social attitudes and favourable personal qualities. It facilitates building emotional bonds with the homeland and national heritage. However, negative consequences of tourist journeys have also been noticed. Many types of qualified tourism (mountain climbing or trekking, canoeing or kayaking, and sailing tourism) require relevant skills and experience, whereas tourists often overestimate their own abilities. As a result, sometimes the risk they take leads to loss of health. Recklessness, a lack of basic professional knowledge, stimulants, violation of the norms of social life, and too ambitious trip schedules belong to the most risky aspects of tourism. They are often caused by the organizers' ignorance of the dangers related to tourist traffic, as well as a lack of sufficient preparation by tourists. Hence, promoting tourist education in the society seems advisable. Tourist guides and guardians play a special role in the process of providing services for tourists. Their qualifications are defined in the education system regulations concerning people who organize tourism at school, namely camp managers, camp tutors, and school excursion leaders. They are all required to possess not only competences to organize tourist and leisure events, but also pedagogical skills and personal qualities enabling them to accomplish educational targets and ensure young people's safety.

Since the school year 2009/2010, a new curriculum for general education has been implemented in the Polish schools (beginning with the 1st class of the primary school and the 1 st class of the lower secondary school), planned to be introduced within 6 years [3]. It has changed a number of significant physical education issues at all levels of education. However, if the existing opportunities are to be optimally exploited and the duties imposed by the physical education curriculum fulfilled, other legal regulations must also be respected [4]. According to them, physical education can be taught within two paths, based on the mixed strategy. It comprises compulsory lessons (the same for all pupils) and optional classes (compulsory classes of a pupil's individual choice in groups created among classes or forms). 
A pupil is treated as a co-organizer of the education process and the school is obliged to provide conditions for an independent and conscious choice of the physical activity appropriate for their interests, developmental needs, and psychophysical abilities. Physical education classes (beginning with the 4th class of the primary school, through the lower secondary school, and in the upper secondary school) should be partly organized in groups of interest, on the basis of the pupil's decision. Thus, physical education teachers have to create their own offer of classes, including diverse forms of physical activity in optional groups. The classes may take place in groups consisting of pupils from different departments (of the same age), and from different forms (of various age) in the lesson, extracurricular, or outdoor modes. For the primary and lower secondary school levels, a $2+2$ model is suggested, including 2 obligatory hours in the lesson mode and 2 optional hours of the chosen activity; for the level of the upper secondary school, a 1+2 model is proposed (1 obligatory hour and 2 optional hours).

The presented model of physical education system creates chances for:

- fulfilling pupils' expectations, which results in their higher motivation and commitment: they practise what they like, what they have individually chosen from the offer;

- greater satisfaction from the teacher's work: conducting classes with pupils who are interested in the chosen form of the physical activity;

- an increase of personal, professional and social prestige of a physical education teacher: broader participation in the school life, bigger opportunities for both professional and personal development;

- a higher autonomy of the school and the teacher in organizing and choosing the teaching content;

- school promotion: creating an interesting and competitive offer of optional classes.

According to the mentioned regulations, every school is obliged to prepare its own offer of optional classes for pupils. Their main purpose is to fulfil pupils' expectations referring to school physical education through providing them with opportunities to gain knowledge and develop skills in the areas of their interest and those which are accessible for them in the context of their level of fitness and organism efficiency.

The attractiveness of the optional classes offer depends on the diverse qualifications and experiences of teachers and on the way sports facilities are exploited. It is possible, if agreed with the institution in charge of the school, to sign a contract concerning the use of other schools' and non-school institutions' facilities. There are four types of optional classes distinguished: sport, recreational and health, dance and tourism. They should take place regularly, at least twice a week ( 2 school lesson hours). However, the optional classes can be cumulated, especially in the tourist profile, which is related to the kind of tourism, level of pupils' advancement, or season of the year. The following rules should be observed: 2-hour classes take place once a week, 4-hour classes every second week, 6-hour classes every third week, and 8-hour classes every fourth week. Such classes might be also scheduled for Saturdays.

Tourist classes are designed for all pupils who want to take part in them. Their aim is to arouse tourist and sightseeing interests, as well as to encourage pupils to gain badges of qualified tourism. Within the classes, the school can propose pupils one or several kinds of tourism, according to their interests and the topography of the environment, e.g. hiking, 
cycling, canoing or participating in mountain tourism. Duties that are imposed as a result of the regulations must be remembered when tourist classes are organized [5].

The aim of the survey was to identify physical education students' self-assessment concerning their preparation for conducting tourism classes as a part of compulsory physical education lessons at school. The authors also tried to specify the profile of a school tourism teacher preferred by students.

The following research questions were formulated:

1. What is the students' understanding of a school tourism teacher's objectives and scope of duties?

2. Which forms of organizing sightseeing and school tourism activities are preferred by the students who are potential school tourism teachers?

3. What qualities of character should a tourism teacher (responsible for organizing trips and hiking camps) possess?

4. Which contents of the school tourism course syllabus do students find crucial in developing their competence as school tourism teachers?

\section{$1 \quad$ Study Project and Methods}

The survey was carried out among students of the $1^{\text {st }}$ year students of the $2^{\text {nd }}$ degree studies after completing the subject of school tourism, which is taught within a 30-hour course and ended with an examination. The methods of a diagnostic poll and a questionnaire were applied, with the HGK/PO-2009/10-II/I/IS questionnaire prepared by the authors. The study was anonymous and voluntary, and involved 114 students (60 women and 54 men). The average examination grade of the participants was 3.91 ( 4.14 for women and 3.66 for men).

\section{$2 \quad$ Study Results and Discussion}

The surveyed student group (Table 1) appointed promotion of diverse active recreation forms and the pro-health influence on children and young people from ecologically endangered areas as the key objectives of school tourism. Female students emphasized the educational function (preventing social pathology), while male students stressed the role of discovering the environment, tradition and culture.

Both female and male students are in agreement on the primary form of tourism classes. These ought to be travelling events, such as 'green schools' or 'ecological schools' (Table 2). The differences can be noticed regarding the tourist events - male students tend to prefer trips which do not require specialized skills from the participants, while female students prefer qualified tourism, e.g. hiking, cycling, canoeing or sailing tourism. 
Tab. 1: Students' opinions concerning a school tourism teacher's objectives and scope of duties

\begin{tabular}{|c|c|c|c|c|c|c|}
\hline \multicolumn{2}{|c|}{ All respondents } & \multicolumn{2}{|c|}{ Female students } & \multicolumn{2}{|c|}{ Male students } & \multirow[t]{2}{*}{ Ranking } \\
\hline Objective No. & Points & Objective No. & Points & Objective No. & Points & \\
\hline 8 & 676 & 8 & 373 & 7 & 317 & 1 \\
\hline 7 & 664 & 7 & 347 & 1 & 316 & 2 \\
\hline 2 & 644 & 9 & 338 & 5 & 314 & 3 \\
\hline 5 & 638 & 2 & 336 & 2 & 308 & 4 \\
\hline 9 & 631 & 10 & 326 & 3 & 307 & 5 \\
\hline 1 & 629 & 5 & 324 & 8 & 303 & 6 \\
\hline 3 & 620 & 4 & 323 & 9 & 293 & 7 \\
\hline 10 & 618 & 6 & 320 & 10 & 292 & 8 \\
\hline 4 & 591 & 1 & 313 & 4 & 268 & 9 \\
\hline 6 & 583 & 3 & 313 & 6 & 263 & 10 \\
\hline
\end{tabular}

Objective No.:

Discovering the country, its environment, tradition, monuments of culture and history

Discovering the culture and language of other countries

Gaining knowledge in various spheres of social, economic and cultural life

Supporting school and family in the upbringing process

Promoting the principles of environment protection and abilities to take advantage of its resources among children and youth

Improving fitness

Improving the health condition of children and young people from ecologically endangered areas

Promoting diverse active recreation forms

Preventing social pathology

Learning the principles of safe behaviour in different situations

Source: own

Tab. 2: Ranking of forms of sightseeing and school tourism preferred by students

\begin{tabular}{|r|r|r|r|r|r|r|}
\hline \multicolumn{2}{|c|}{ All respondents } & \multicolumn{2}{|c|}{ Female students } & \multicolumn{2}{|c|}{ Male students } & \multirow{2}{*}{ Ranking } \\
\cline { 2 - 6 } Form & \multicolumn{1}{c|}{ Points } & \multicolumn{1}{c|}{ Form } & \multicolumn{1}{c|}{ Points } & Form & \multicolumn{1}{c|}{ Points } & \\
\hline 5 & 973 & 5 & 520 & 5 & 453 & $\mathbf{1}$ \\
\hline 4 & 906 & 4 & 493 & 3 & 436 & $\mathbf{2}$ \\
\hline 1 & 878 & 3 & 455 & 2 & 422 & $\mathbf{3}$ \\
\hline 2 & 876 & 1 & 450 & 1 & 421 & $\mathbf{4}$ \\
\hline 3 & 872 & 2 & 442 & 4 & 413 & $\mathbf{5}$ \\
\hline
\end{tabular}

Forms:

Subject trips, complementing the compulsory curriculum

Sightseeing and tourist trips, which do not require a high level of fitness or specialized skills from the participants

Sightseeing and tourist events, such as bivouacs, contests or competitions

Qualified tourism events, such as lowland and mountain hiking, cycling, canoeing and sailing tourism

Travelling events, such as 'green schools', 'winter schools', or 'ecological schools'

Source: own

The main source of funding for tourism classes (Table 3), unanimously recognized by all students, should be the funds earned by youth organizations and the pupils self-government. Cooperation with adults (parental council, school board, sponsors) is the last possibility that should be taken into consideration. 
Tab. 3: Ranking of methods for gaining funds for school tourism classes preferred by students

\begin{tabular}{|r|r|r|r|r|r|r|}
\hline \multicolumn{2}{|c|}{ All respondents } & \multicolumn{2}{|c|}{ Female students } & \multicolumn{2}{c|}{ Male students } & \multirow{2}{*}{ Ranking } \\
\cline { 1 - 6 } Funds & Points & Funds & Points & Funds & Points & \\
\hline 2 & 298 & 2 & 157 & 2 & 141 & $\mathbf{1}$ \\
\hline 1 & 282 & 1 & 150 & 3 & 139 & $\mathbf{2}$ \\
\hline 3 & 282 & 4 & 144 & 1 & 132 & $\mathbf{3}$ \\
\hline 4 & 274 & 3 & 143 & 4 & 130 & $\mathbf{4}$ \\
\hline
\end{tabular}

Funds:

From pupils' contribution

Earned by pupils self-government and youth school organizations

From financial means earned by pupils

From financial means donated by the parental council or the school board, individuals or other institutions

Source: own

Weekend trips are to be primarily the source of leisure for youth (Table 4). Students predominantly view them as the means of recreation.

Tab. 4: The key functions of weekend trips

\begin{tabular}{|r|r|r|r|r|r|r|}
\hline \multicolumn{2}{|c|}{ All respondents } & \multicolumn{2}{|c|}{ Female students } & \multicolumn{2}{c|}{ Male students } & \multirow{2}{*}{ Ranking } \\
\cline { 1 - 6 } Function & Points & Function & Points & Function & Points & \\
\hline 1 & 248 & 1 & 131 & 1 & 117 & $\mathbf{1}$ \\
\hline 2 & 237 & 2 & 121 & 2 & 116 & $\mathbf{2}$ \\
\hline 3 & 200 & 3 & 109 & 3 & 9 & $\mathbf{3}$ \\
\hline
\end{tabular}

Functions:

Recreation

Discovering the surroundings of pupils' residence

Preparation for longer trips and holiday walking tours

Source: own

The majority of the surveyed students shared the opinion about the form of multi-subject excursions (Figure 1). Students believe that the excursions should combine qualified tourism with discovering the culture and folklore of the particular region.

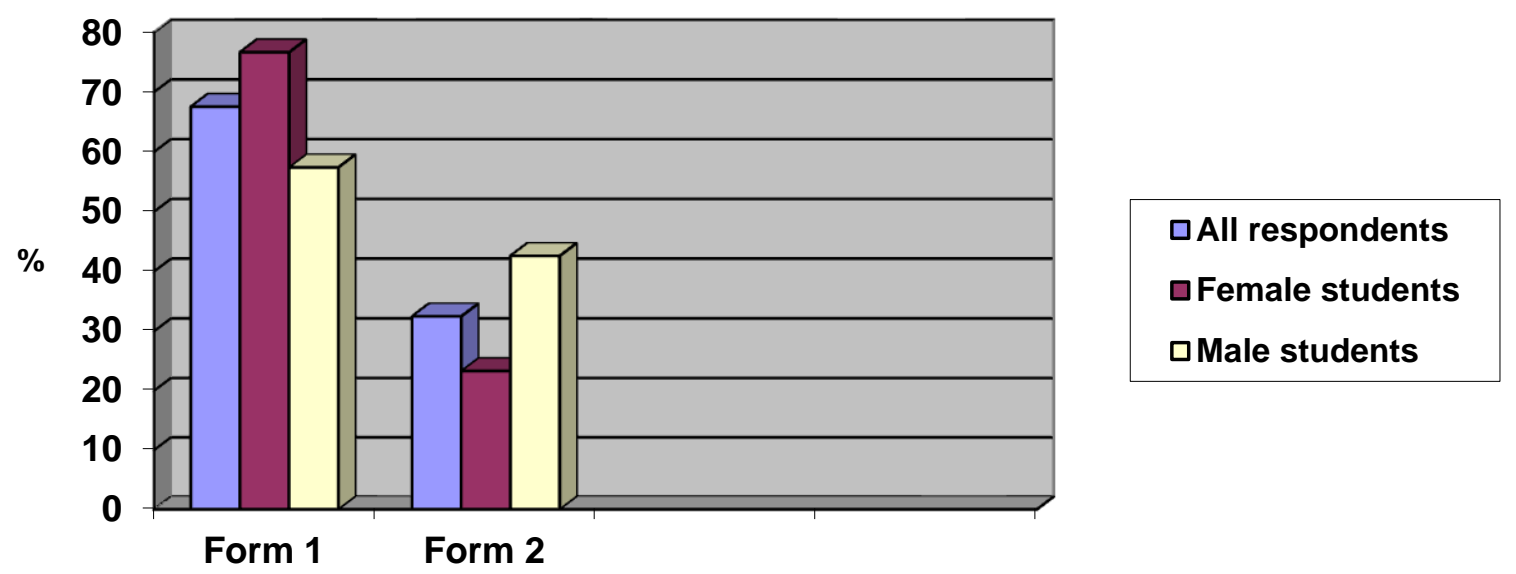

Form 1: with elements of qualified tourism (e.g. mountain tourism, regional culture, folklore)

Form 2: with elements of qualified tourism and environmental research (e.g. mountain tourism, regional history, and problems of the inhabitants' professional profile transformation)

Source: own

Fig. 1: Forms of multi-subject excursions preferred by the respondents 
There is a diversity of opinions on the preferred kinds of territory trips (Figure 2). Half of the respondents chose domestic trips, the second half - foreign trips (preferred more often by female students).

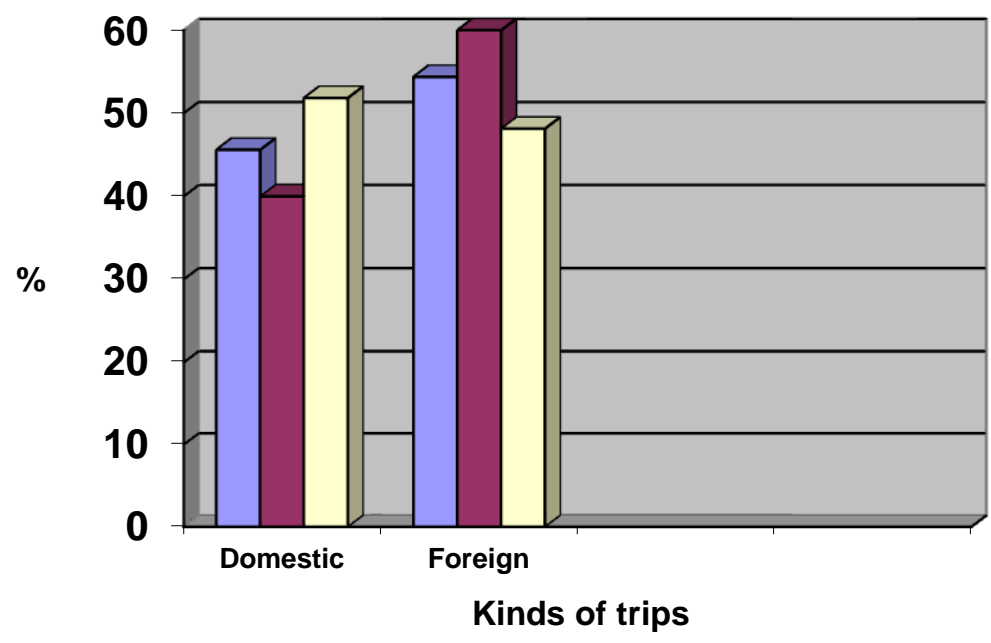

\section{$\square$ All respondents $\square$ Female students $\square$ Male students}

Source: own

Fig. 2: Kinds of territory trips preferred by the respondents

Effective teaching of tourism classes, which includes covering the curriculum and reaching the assigned objectives, requires from a teacher not only knowledge and organizational skills, but also certain qualities of character. What personality features should a tourism (trip and hiking camps) teacher embody in the opinion of the potential leaders of the activity? Which features can be their authority builders among school youth and which can help to support fulfilling their duties of school tourism animators? The respondents ranked the most desirable characteristics (out of 30 proposed) and the most undesirable ones (out of 20 proposed).

According to the respondents (both female and male students) taking part in the ranking, the least important features (ranked from the $26^{\text {th }}$ to the $30^{\text {th }}$ ) for the personal profile of a tourism teacher are: resourcefulness, consideration, vigorousness, thoughtfulness and sensitivity to moral values.

In the students' opinion, an ideal profile of a tourism teacher (Table 5) consists of particular directional features (responsibility, the ease of establishing contacts with young people, and friendliness) and instrumental ones (perfection in action and professionalism, as well as ability to present knowledge in an attractive manner). Students also believe that teachers should apply an individual approach to young people, know the regulations concerning the trip safety, be friendly, patient and understanding.

The least important negative features (ranked from the $16^{\text {th }}$ to the $20^{\text {th }}$ ) for the personal profile of a tourism teacher, according to the respondents, are: capriciousness, coldness, and choosing the easy way (female students), as well as bossiness, coldness, and choosing the easy way (male students). 
Tab. 5: Ranking of positive character features of a school tourism teacher

\begin{tabular}{|c|c|c|c|c|c|c|}
\hline \multicolumn{2}{|c|}{ All respondents } & \multicolumn{2}{|c|}{ Female students } & \multicolumn{2}{|c|}{ Male students } & \multirow[t]{2}{*}{ Ranking } \\
\hline Feature & Points & Feature & Points & Feature & Points & \\
\hline Responsible & 2588 & Responsible & 1333 & Responsible & 1258 & 1 \\
\hline $\begin{array}{l}\text { Establishing } \\
\text { contacts with } \\
\text { young people } \\
\text { easily }\end{array}$ & 2406 & $\begin{array}{l}\text { Establishing } \\
\text { contacts with } \\
\text { youth easily }\end{array}$ & 1333 & Friendly & 1127 & 2 \\
\hline $\begin{array}{l}\text { Perfect in action } \\
\text { and professional }\end{array}$ & 2385 & $\begin{array}{l}\text { With ability to } \\
\text { present } \\
\text { knowledge in an } \\
\text { attractive manner }\end{array}$ & 1295 & $\begin{array}{l}\text { Perfect in action } \\
\text { and } \\
\text { professional }\end{array}$ & 1090 & 3 \\
\hline $\begin{array}{l}\text { With ability to } \\
\text { present } \\
\text { knowledge in an } \\
\text { attractive manner }\end{array}$ & 2285 & $\begin{array}{l}\text { Perfect in action } \\
\text { and professional }\end{array}$ & 1295 & $\begin{array}{l}\text { Establishing } \\
\text { contacts with } \\
\text { youth easily }\end{array}$ & 1073 & 4 \\
\hline $\begin{array}{l}\text { With an } \\
\text { individual } \\
\text { approach to } \\
\text { young people }\end{array}$ & 2209 & $\begin{array}{l}\text { Knowing the } \\
\text { regulations } \\
\text { concerning the } \\
\text { trip safety }\end{array}$ & 1210 & Kind & 1046 & 5 \\
\hline $\begin{array}{l}\text { Knowing the } \\
\text { regulations } \\
\text { concerning the } \\
\text { trip safety }\end{array}$ & 2190 & $\begin{array}{l}\text { With an } \\
\text { individual } \\
\text { approach to } \\
\text { young people }\end{array}$ & 1201 & Warm-hearted & 1043 & 6 \\
\hline Understanding & 2136 & Patient & 1138 & Understanding & 1034 & 7 \\
\hline Patient & 2132 & $\begin{array}{l}\text { Able to provide } \\
\text { first aid }\end{array}$ & 1129 & Intelligent & 1026 & 8 \\
\hline Intelligent & 2111 & Understanding & 1102 & Impartial & 1024 & 9 \\
\hline Friendly & 2107 & $\begin{array}{l}\text { Diligent in } \\
\text { his/her } \\
\text { commitments }\end{array}$ & 1100 & $\begin{array}{l}\text { Cheerful, with a } \\
\text { sense of } \\
\text { humour }\end{array}$ & 1010 & 10 \\
\hline
\end{tabular}

Source: own

The personality factors unfavourable for a tourism teacher (Table 6) include the following features: brutality, neglecting youth, mendaciousness, a tendency to drink alcohol, and quarrelsomeness.

In accordance with the Regulation of the Minister of Science and Higher Education [6], the curriculum for the $2^{\text {nd }}$ degree studies in the scope of school tourism comprises the following contents:

1. Tourism as a Social Phenomenon (TSP),

2. Outline of Tourism History (OTH),

3. Organization of Tourism and Sightseeing in Poland (OTSP),

4. Safety in Tourism (ST),

5. Protection of the Environment in Tourism (PET),

6. Selected Forms of Active Tourism (FAT),

7. Legal Framework of Tourist Activity (LFTA). 
Tab. 6: Undesirable features of a teacher responsible for trip and hiking camp organisation

\begin{tabular}{|l|r|l|r|l|r|r|}
\hline \multicolumn{2}{|c|}{ All respondents } & \multicolumn{2}{c|}{ Female students } & \multicolumn{2}{c|}{ Male students } & Ranking \\
\hline \multicolumn{1}{|c|}{ Feature } & Points & \multicolumn{1}{|c|}{ Feature } & Points & \multicolumn{1}{c|}{ Feature } & Points & \\
\hline Brutal & 1582 & $\begin{array}{l}\text { Neglecting } \\
\text { youth }\end{array}$ & 850 & Malicious & 757 & $\mathbf{1}$ \\
\hline Malicious & 1494 & Brutal & 830 & Brutal & 752 & $\mathbf{2}$ \\
\hline $\begin{array}{l}\text { Neglecting } \\
\text { youth }\end{array}$ & 1473 & $\begin{array}{l}\text { With a tendency } \\
\text { to drink alcohol }\end{array}$ & 799 & Quarrelsome & 672 & $\mathbf{3}$ \\
\hline Quarrelsome & 1465 & Quarrelsome & 793 & $\begin{array}{l}\text { With a tendency } \\
\text { to drink alcohol }\end{array}$ & 661 & $\mathbf{4}$ \\
\hline $\begin{array}{l}\text { With a tendency } \\
\text { to drink alcohol }\end{array}$ & 1460 & Malicious & 737 & Mendacious & 624 & $\mathbf{5}$ \\
\hline $\begin{array}{l}\text { Intolerant } \\
\text { Mendacious }\end{array}$ & 1262 & Egoistic & 668 & $\begin{array}{l}\text { Neglecting } \\
\text { youth }\end{array}$ & 623 & $\mathbf{6}$ \\
\hline Unfriendly & 1250 & Absent-minded & 657 & Intolerant & 611 & $\mathbf{7}$ \\
\hline Egoistic & 1231 & Bossy & 657 & Unfriendly & 609 & $\mathbf{8}$ \\
\hline Arrogant & 1203 & Intolerant & 654 & Arrogant & 572 & $\mathbf{9}$ \\
\hline
\end{tabular}

Source: own

The aim of the research included discovering the students' opinion with respect to the usefulness of these contents in the development of their professional competences and their self-assessment within the scope of the competences. The results are depicted in Tables 7 and 8.

Tab. 7: Ranking of students' opinions concerning the importance of the curriculum contents in the school tourism course for teaching tourism classes

\begin{tabular}{|l|r|l|l|l|r|r|}
\hline \multicolumn{2}{|c|}{ All respondents } & \multicolumn{2}{|c|}{ Female students } & \multicolumn{2}{c|}{ Male students } & Ranking \\
\cline { 1 - 6 } Contents & Points & Contents & Points & Contents & Points & \\
\hline FAT (6) & 528 & FAT & 285 & FAT & 243 & $\mathbf{1}$ \\
\hline ST (4) & 498 & OTSP & 269 & TSP & 234 & $\mathbf{2}$ \\
\hline OTSP (3) & 479 & ST & 268 & ST & 230 & $\mathbf{3}$ \\
\hline TSP (1) & 469 & PET & 237 & PET & 220 & $\mathbf{4}$ \\
\hline PET (5) & 457 & TSP & 235 & OTSP & 210 & $\mathbf{5}$ \\
\hline LFTA (7) & 400 & LFTA & 226 & OTH & 194 & $\mathbf{6}$ \\
\hline OTH (2) & 359 & OTH & 165 & LFTA & 174 & $\mathbf{7}$ \\
\hline
\end{tabular}

Source: own

Particular contents of the school tourism course provide students with the proper training for the role of a tourist teacher (Table 7). These are, first of all, the contents related to the selected forms of active tourism and safety in tourism, as well as organization of tourism and sightseeing in Poland (for female students), and tourism as a social phenomenon (for male students). All of the students do not appreciate the applicability of contents connected with the legal framework of tourist activities. 
Tab. 8: Ranking of students' opinions concerning the level of their competences for conducting tourism classes developed during the school tourism course

\begin{tabular}{|l|r|l|r|l|l|r|}
\hline \multicolumn{2}{|c|}{ All respondents } & \multicolumn{2}{c|}{ Female students } & \multicolumn{2}{c|}{ Male students } & Ranking \\
\cline { 1 - 5 } Contents & Points & Contents & Points & Contents & Points & \\
\hline FAT (6) & 539 & FAT & 316 & ST & 252 & $\mathbf{1}$ \\
\hline ST (4) & 534 & ST & 282 & OTSP & 230 & $\mathbf{2}$ \\
\hline OTSP (3) & 489 & OTSP & 259 & FAT & 223 & $\mathbf{3}$ \\
\hline PET (5) & 446 & PET & 227 & PET & 219 & $\mathbf{4}$ \\
\hline TSP (1) & 431 & TSP & 225 & TSP & 206 & $\mathbf{5}$ \\
\hline LFTA (7) & 380 & LFTA & 197 & OTH & 198 & $\mathbf{6}$ \\
\hline OTH (2) & 373 & OTH & 175 & LFTA & 183 & $\mathbf{7}$ \\
\hline
\end{tabular}

Source: own

The self-assessment of the students' preparation for the role of a school tourism teacher (Table 8) is consistent with their ranking of the curriculum contents. The students seem to feel most competent in the forms of active tourism and safety in tourism. They consider themselves worse prepared as far as their knowledge of tourist activity legal framework and history of tourism are concerned.

\subsection{Students' Knowledge about the Organization of School Trips and Events}

According to the Regulation of the Minister of National Education and Sport [5], a set of questions concerning formal and legal requirements for teachers who organize school tourism activity was formulated. All types of requirements included in the questionnaire are obligatory so students' answers with respect to the school excursion leaders rights and the required documentation should have been positive.

The students' knowledge concerning the responsibility for leading school trips appears to be rather modest (Figure 3). Nearly half of them do not know who is allowed to be a trip leader.
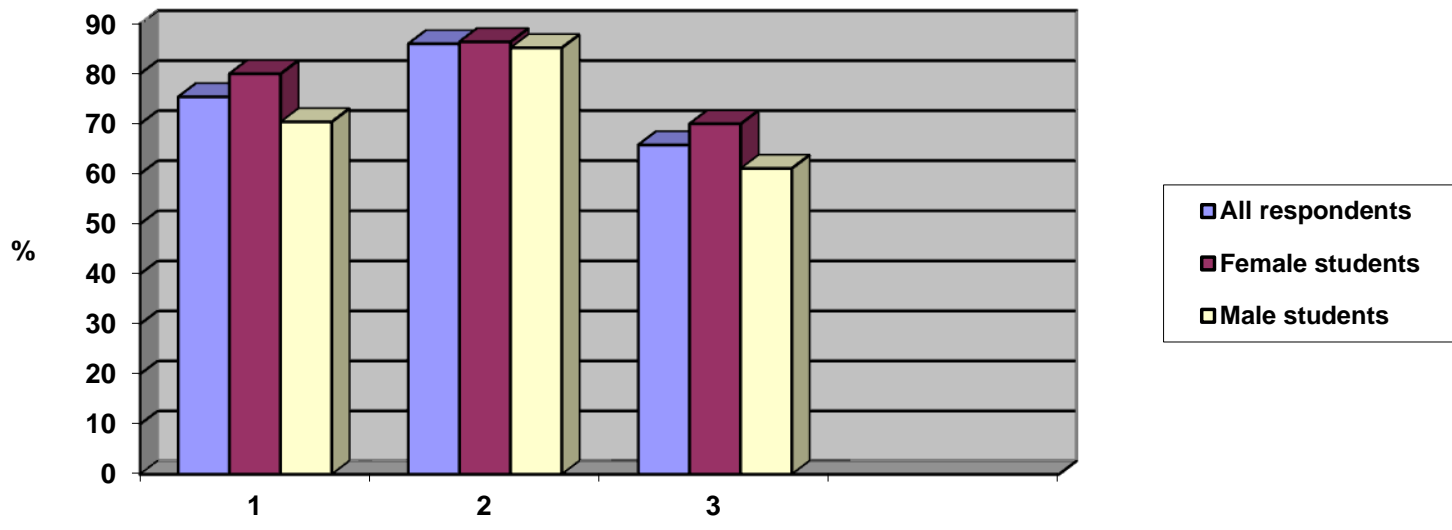

A trip or tourist event leader must be a person who (tick the correct answer):

1. Has completed a school trip course

2. Is a scout instructor

3. Has qualifications of a tourist guide or leader, or of an instructor of qualified tourism or tour guide

4. A qualified tourism event manager - must be a trainer or instructor of a relevant sports discipline (or point 3)

Source: own

Fig. 3: Incorrect students' answers concerning a person who is allowed to be a trip leader

The students are slightly more familiar with the procedure of documenting a school trip organization (Figure 4). The biggest number of incorrect answers is related to documenting a 
scheduled trip to the adequate authorities (notifying the institution in charge of school and the pedagogic supervision institution). It is worth noticing that female students are better prepared for the procedure.

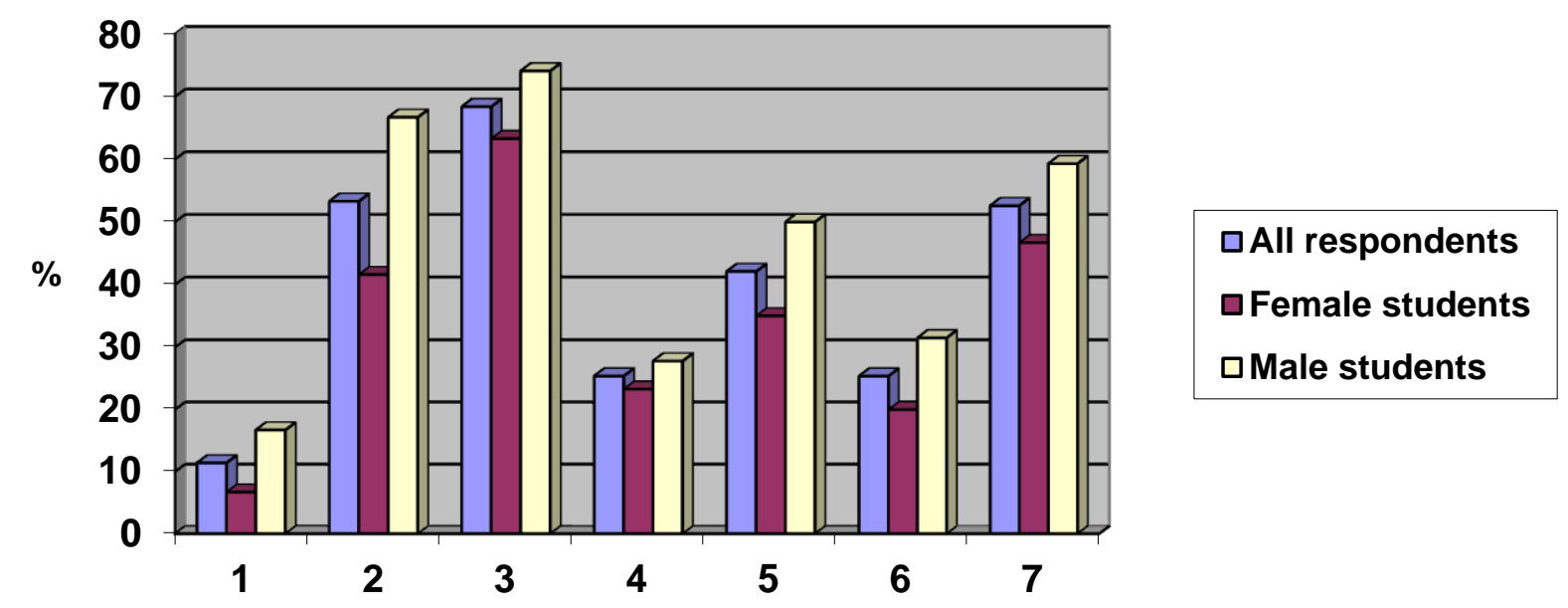

Documents required to organize a trip (tick the correct answer):

1. Permission of a school headmaster

2. Notifying an institution in charge of school

3. Notifying the pedagogic supervision institution

4. Trip schedule

5. Declaration of observing the safety principles during the trip

6. Insurance policy for trip participants

7. Confirmation of booked services by the trip organizer accompanied by possible prepayment documents Source: own

Fig. 4: Incorrect students' answers concerning the documents required for a school trip organization

\section{$3 \quad$ Summary}

The research conducted by Denek [7] presents the reality less optimistic in terms of the perspective for developing school sightseeing and tourism. Denek concludes that the amount of teachers in Poland trained and willing to teach sightseeing and tourism outside the school facilities ranges between 4 and $6 \%$ of the teacher community. Further development of school tourism will depend, among others, on the level of teachers' preparation in the field of professional pedagogical, psychological, as well as sightseeing and tourist qualifications. Efficient organization of school tourism by physical education teachers will be determined by both the qualifications of tourism leaders (which should be provided to students during their physical education studies) and their personal features, resulting from a set of particular character qualities. The new perspective of physical education in schools in the form of tourism classes opens attractive opportunities for physical education teachers to educate young people about the free time values through promotion of tourism and discovering of their home country.

Tourism classes can shape the attitudes of the young people towards leisure and recreation needs in the context of everyday life, weekends and holidays. A research project carried out among the citizens of the Wroclaw city in Poland emphasizes the opportunities to develop tourism in urban centres [8]. They offer substantial and diverse tourist resources for every day, weekend or holiday tourism. Tourist habits should be modelled, among others, through tourist activities during tourism classes at school. However, the research project conducted among the potential physical education and school tourism teachers reveals a heterogeneous 
picture of their preparation for this role. Students perceive weekend trips more in the terms of leisure (recreation) than as a way to discover the pupils' closest environment. The forms of sightseeing and school tourism preferred by students are tourist events, such as 'green schools', 'winter schools' or 'ecological schools', as well as qualified tourism, and foreign trips. The students' knowledge on trip organization is not sufficient. It has been proved by the incorrect answers of more than half of the students with respect to the documents required for organizing trips and the functions of their leaders. On the other hand, the students emphasize the importance of the contents learned during the studies and highly assess their competence in such subjects as the selected forms of active tourism and safety in tourism, organization of tourism and sightseeing in Poland (female students), and tourism as a social phenomenon (male students). Generally, the students underestimate the significance of thorough knowledge of the tourist activity legal framework.

Simultaneously, the surveyed students indicated the following crucial personal qualities of a school tourism teacher: responsibility, perfection in action and professionalism, and deep knowledge of the regulations concerning the trip safety.

Tourism classes in the process of physical education are intended for all interested pupils. Their aim is to awaken the pupils' interest in tourism and sightseeing and to encourage them to acquire the qualified tourism badges. Organization of tourist activities imposes particular obligations on a physical education teacher arising from the relevant regulations on the conditions and methods of school sightseeing and tourism organization.

\section{Conclusions}

1. In the physical education students' opinion, the main objective of school tourism is to promote various forms of active recreation.

2. As potential school tourism teachers, the students prefer tourist events ('green schools', 'ecological schools'); they consider thematic trips or sightseeing and tourist trips less important.

3. The students agree that a school tourism teacher should possess an inner personal integrity and should be characterized by responsibility, the ease of establishing contacts with young people, as well as perfection in action and professionalism.

4. Students highly appreciate the curriculum contents concerning the forms of active tourism and safety in tourism; however, they tend to underestimate the need for the thorough knowledge of tourist activity legal framework. They view their competences in a similar way.

\section{Literature}

[1] NOWAKOWSKA, A.: Turystyka jako zjawisko społeczno-ekonomiczne. In: Gołembski, G. (ed.), Kompendium wiedzy o turystyce. PWN, Warszawa, 2009, pp. 144. ISBN 978-83-01-15814-9.

[2] GOŁEMBSKI, G.: Związki turystyki z sektorem publicznym. In: Gołembski, G. (ed.), Kompendium wiedzy o turystyce. PWN, Warszawa, 2009, pp. 131-148. ISBN 978-8301-15814-9.

[3] Ministry of National Education and Sport: Regulation of the Minister of National Education and Sport issued on the 23rd December 2008 concerning the curriculum for kindergartens and general education in different school types (Journal of Laws, 2009, No. 4, item 17). 
[4] Ministry of National Education and Sport: Regulation of the Minister of National Education and Sport issued on the $19^{\text {th }}$ August 2009 concerning the accepted forms of implementing two hours of obligatory physical education classes (Journal of Laws, No. 136, item 1116).

[5] Ministry of National Education and Sport: Regulation of the Minister of National Education and Sport issued on the 8th November 2001 concerning conditions and modes of organizing tourism and sightseeing by state kindergartens, schools, and other educational institutions (Journal of Laws, No. 135, item 1516, as amended).

[6] Ministry of Science and Higher Education: Regulation of the Minister of Science and Higher Education issued on the 12th July 2007 concerning the standards of education for particular degree courses and levels of education, as well as the procedure of establishing and requirements which a university has to met to organize interdisciplinary programmes and macro-direction studies (Journal of Laws, No. 1164, Annex No. 113).

[7] DENEK, K.: Edukacja szkolna i pozalekcyjna. WSPiA, Poznań, 2009. ISBN 978-8360038-10-9.

[8] KLEMENTOWSKI, K.; MIKUŁOWSKI, B.; WYRZYKOWSKI, J.: Determinanty środowiskowe realizacji wypoczynku weekendowego mieszkańców Wrocławia. Human Movement. 2002, Vol. 2, Issue 6, pp. 52-57. ISSN 1508-5287.

Piotr Oleśniewicz, Ph.D., Assoc. Prof.; Halina Guła-Kubiszewska, Ph.D., Assoc. Prof.; Julita Markiewicz-Patkowska, Ph.D. 


\section{ŠKOLNÍ TURISTIKA - NOVÁ PERSPEKTIVA REALIZACE TĚLESNÉ VÝCHOVY VE ŠKOLÁCH}

Cílem uskutečňovaného průzkumu je zjiššění názorů studentů tělesné výchovy týkajících se jejich prŕpravy $\mathrm{k}$ realizaci turistické výuky $\mathrm{v}$ rámci povinných hodin tělesné výchovy ve školách. Dále byla snaha stanovit vzor učitele školní turistiky, který studenti upřednostňují. Průzkum byl uskutečňován mezi všemi studenty 1. ročníku druhého stupně studia po získání zápočtu z předmětu, „školní turistika”. Tento předmět má 30 výukových hodin a končí závěrečnou zkouškou. Byla využita dotazníková metoda diagnostického výzkumu. Byl uplatněn dotazník HGK/PO-2009/10-II///IS zpracovaný autorem. Průzkum měl anonymní a dobrovolný charakter a zúčastnilo se jej 114 studentů.

\section{SCHULTOURISMUS: EINE NEUE PERSPEKTIVE DER IMPLEMENTIERUNG VON LEIBESERZIEHUNG AN POLNISCHEN SCHULEN}

Ziel dieser Studie ist die Untersuchung der Meinung polnischer Sportstudenten über ihre Fähigkeit, Tourismusunterricht als Teil der obligatorischen Leibeserziehung in der Schule zu erteilen. Die Autoren waren ebenfalls bemüht, das von den Studenten bevorzugte Paradigma eines Tourismuslehrers zu bestimmen. Die Studie wurde unter allen Studenten des ersten Jahrgangs der Studien der zweiten Stufe nach Abschluss des Faches Schultourismus durchgeführt, welches 30 Wochenstunden umfasst und mit einer Prüfung endet. Es wurden die Methode einer diagnostischen Untersuchung und die Fragebogentechnik angewendet, wobei der HGK/PO-2009/10-I///IS-Fragebogen von den Autoren selbst erstellt wurde. Die Studie verlief anonym und auf freiwilliger Basis. 114 Studenten beteiligten sich daran.

\section{TURYSTYKA SZKOLNA - NOWA PERSPEKTYWA REALIZACJI WYCHOWANIA FIZYCZNEGO W SZKOLE}

Celem podjętych badań było rozpoznanie opinii studentów wychowania fizycznego na temat przygotowania ich do prowadzenia zajęć turystycznych w ramach obowiązkowych zajęć wychowania fizycznego w edukacji szkolnej. Próbowano także określić preferowany przez studentów wzorzec nauczyciela turystyki szkolnej. Badania zostały przeprowadzone wśród wszystkich studentów I roku studiów II stopnia po zaliczeniu przedmiotu „turystyka szkolna”. Przedmiot ten jest realizowany w wymiarze 30 godzin i kończy się egzaminem. Zastosowano metodę sondażu diagnostycznego techniką ankietową i wykorzystano kwestionariusz ankietowy HGK/PO-2009/10-II///IS własnego autorstwa. Badania miały charakter anonimowy i dobrowolny; wzięło w nich udział 114 studentów. 